URL: http://dergipark.ulakbim.gov.tr/ijhbs/index

Volume: 1, Issue: 3, Year: 2015

http://dx.doi.org/10.19148/ijhbs.81297

\title{
Systemic Family Oriented Program Of Psycho-Education, Effect Of Values Of Spouses And Perceived Social Support On Dyadic Adjustment
}

\author{
Mert Abdullahmert \\ Ministry of National Education, Turkey \\ abdullahmert@gmail.com \\ Murat İskender \\ Sakarya University, Turkey \\ iskender@sakarya.edu.tr
}

\begin{abstract}
In this study, it is aimed to find out the effects of predicting variables on Dyadic Adjustment (DA) and to examine them by a psychoeducational programme. Values and Social Support are considered to be the predictor variables of Dyadic Adjustment (DA) here in this study. The sample participants of this study are randomly chosen, married, and employed two hundred and eleven Turkish couples (211 males and 211 females, 422 participants totally) who were born in the cities of Adana, Çanakkale, Bursa, İstanbul, Osmaniye and Zonguldak. Among these samples, ten participants with low Dyadic Adjustment were chosen randomly for the experiment and control groups. According to the results of experimental study, it can be said that $x$ time effect is reasonable $(p<.05)$ for all the dependent variables of the study, namely Dyadic Adjustment Psychoeducational Programme (DAPP), Marriage Adjustment, Values and Social Support. Psychoeducational Programmes to foster Dyatic Adjustment are effective to increase the marriage adjustment, and values and social support level. Moreover, this effect proved to be ongoing and increasing even after two months' time. The results of the descriptive study and experimental study were discussed in the light of the findings, and suggestions for future researches were investigated and made.
\end{abstract}

Keywords: Values, Systematic Family Theraphy and Perceived Social Support, Dyatic Adjustment.

\section{Introduction}

Today, social differences which are diminishing due to the dizzying changes experienced affect family values. Under the influence of popular culture adopted, it is observed that family members build mostly an individual-centered and pleasure, power and freedom oriented lifestyle and value system. However, despite all these developments, the family is still one of the important building blocks of society (Mert, 2014). Family is defined as a group consisting of individuals consisting of legal and biological bonds (Koerner and Fitzpatrick, 2002) with a variety of roles within a social network (Jagger and Wright (1999) and structure (Peter and Olson, 2005, Schiffman and Kanuk, 2004, Wells and Prensky, 1996) and creating a common culture under one roof (Wilkinson, 1998; Özgüven, 2000). Accordig to Lee (2010), our beliefs about family also affect our judgment for the family. Different values, cultures, and personality and belief systems couples have affect the marital relationship they form (Mert, 2014).

Marriage is the most meaningful interpersonal relationship according to many people (TutarelKışlak, 1997). According to Glading (1998), family is an association formed by individuals who have biological or psychological ties, a historical, emotional and economic union among them and feel themselves to be members of the same household. Marital adjustment can be explained as the spouses' adaptation to daily life and changing conditions in daily life (Spanier, 1976), 
being able to communicate well with each other (Ersanlı and Kalkan, 2008; Sabatelli 1988), having love relationship and functional economic partnership (Ritvo and Glick, 2002) and having a higher quality interaction (Janick, Kamorck, Gwaltney, Shiffman, 2006). A harmonious marriage is defined as a concept wherein couples can communicate with each other (Sabatelli 1988), a dialogue-based communication (Rueter and Korner 2008) and an interaction between couples (Caplan, 1974) exists and much disagreement is not experienced in important parts of their marriage lives. In the marriage relationships, family members continue their life according to a system they create. In this systems approach, family communication difficulties (Deaton, 1998), unresolved parental loss or traumatic conditions, parental management in emotional difficulties cases (Seltzer, 1985) or changing parental care behaviors (Marvin, 1992) can be targeted. According to Pearl et al (2001), together with its strategic importance and problematic issues surrounding it, the family will continue to be a central point during many years.

Family members' behavior is determined by the values they receive during marriage time. Values have been conceptualized by Rokeach (1968), Rokeach (1973) Schwartz and Bilsky (1987), Schwartz (1992) and Schwartz and Boehnke (2004) especially by showing a lot of development in personality and social psychology areas, and different definitions have been made during this development process. Values are closely related to culture in sociological sense, identity in social psychological sense, and personality in psychological sense (Yapıc1, 2004), and they are of versatile fundamental importance in inter-people relationships (Aydin, 2003), in affecting human behavior (Kuşdil and Kağıtçıbaşı, 2000; Ayral, 1992), and in the explanation and orientation of this behavior (Kulaksızoğlu and Dilmaç, 2000). Values are defined as enduring beliefs about the personal and social behavior as a distinctive form and purpose in life (Rokeach, 1973) and criteria they use to characterize other people and events, choose and justify their actions (Schwartz, 1992). In order to facilitate this process in this direction, parents reward their children when they behave according to their own expectations, but reprimand and punish them if they behave away from accepted norms and patterns of behavior. Naturally, if a defect occurs in the family institution, negative impacts will reveal both with the child and the community in a broader sense and will constitute a major problem for the future in terms of the values (Sotomayor-Peterson et al., 2012; Iruonagbe, Chiazor \& Foluke, 2013).

Marriage is associated with problem solving skills of the couple and perceived social support. The first determinant of perceived social support is one's own characteristics, (Sarason and Pierce, 1990), and the belief that people will be provided real help, they are loved, they will be protected and that they are valued and to be arisen when a need to develop a sense of commitment to a social group behavior occurs (Lepore et all, 1991). The concept of social support has been replaced by the more recent concept of perceived social support. Briefly, according to Procidano and Heller (1983), while social support is explained as helping behavior which can be realized, perceived social support is explained as realized helping behavior. There are four main determinants of perceived social support for the family. These are: the person by whom the support is perceived, the person who perceives the support, the communication between these two individuals and the interaction within the families (Branjev et al, 2002). While social support takes an interaction, a person or a relationship as reference (Veiel and Bauman, 1992), perceived social support is defined as the existence and availability of the individuals whom we trust and who are valued and loved (Sarason, Levine, Basham, and Sarason, 1983) and the support the people get from their social and psychological surroundings (Y1ldirım, 1997).

Social support has been evaluated as the idea that the individual is approved and respected by their surroundings and they obtained acquisition (Sorias 1988), and has been defined as the perception of the support-receiver in people's attitudes and actions (Hupcey 1998; Pearson, 
1990) and the provision of support through support-receiver and support-provider between at least two individuals (Shumaker and Brownell 1984). Hupcey (1998) describes social support as the positive interaction or useful behavior provided to a person in need. Sarason et al (1983) define social support as the totality of the help an individual can get from individuals around in the face of a problem or when he or she wants to relax psychologically. Perceived support not only provides an individual with the opportunity of a subjective and cognitive assessment but also leads to a mutual cooperation which he established with the society in which he exists and which he evaluated. In other words, perceived social support is the feeling of "you are loved, you are precious and you're unconditionally accepted" (Batool, 2014, De La Iglesia, Stover, Fernandez Liporace M., 2014). Therefore, perceived social support, theoretically, is described as the type and the nature of the perception the individual establishes by sharing with people around (Batool, 2014). In the light of all this assessment, it can be said that the values family members bring their family backgrounds and the effect of values they acquire during the marriage are influential for marital harmony as well as the perceived social support.

\section{Method}

\subsection{Participants}

The study group of this research consists of couples who are married, employed and living in the cities of Adana, Çanakkale, Bursa, İstanbul, Osmaniye and Zonguldak. The experimental and control groups were 211 married couples ( 211 females, 211 males, a total of 422 people). The subjects of the research are 10 couples who are living in Çanakkale, whose dyadic adjustment are low, who are married and employed. The experimental and control groups each include 10 members as five women and five men ( 5 couples).

\subsection{Instruments}

In this study, Value Scale (VS), Dyadic Adjustment Scale (DAS), Multidimensional Perceived Social Support Scale (HDRS) and the Personal Information Form scales were used.

\subsubsection{Value Scale (VS)}

For all values expressed in the Value Scale developed by Dilmaç and Arıcak (2007), in the context of principal component analysis, exploratory factor analysis was performed. KaiserMeyer-Olkin sampling adequacy value was found as .926 and the approximate chi-square value of the Bartlett Sphericity test was found as 14543.11 ( $\mathrm{P}<.001)$ respectively. When the rotation matrix components performed by matrix components and varimax method are examined, it has been seen that all values are divided into 13 factors describing the 65.37 's $\%$ of the total variance.

\subsubsection{Dyadic Adjustment Scale (DAS)}

Developed by Spanier (1976), DAS (Dyadie Adjustment Scale) aims to measure the perception of the nature of the relationship of the married or cohabitating couples. The scale consists of 32 items and in addition to the total score, four subscales scores can be calculated from the scale.

These are peer consensus (dyadic consensus), co satisfaction (dyadic satisfaction), peer integration (dyadie cohesion) and emotional expression (affectional expression) scales. The lowest score and the highest score obtained from the full scale is 0 and 151 respectively. The rise in total points shows the total double harmony in marriage. Scores being lower than 98 indicates marriage incompatibility.

\subsubsection{Multidimensional Perceived Social Support Scale (HDRS)}

It is a Likert-type self-assessment scale developed by Zimet, Dahlem, Zimet and Farley (1988) and consisting of 12 items and measuring the adequacy of resources for the social support of individuals. The scale can measure the source of perceived social support in three dimensions as family, friends and a special person. The first adaptation of the scale into Turkish was made by 
Eker and Akar (1995) and later revised (Eker, Arkar and Yaldız, 2001) and it was finalized. Turkish version of the scale, as in the original, consists of three subscales indicating the source of the perceived social support (friends, family and a special person) and 12 items.

\subsection{Procedure}

In the study, the effects of the systemic family-oriented psycho-educational program on values, perceived social support and couple compliance were examined. In this study, in order to determine the impacts of the "Psycho- educational program to increase the Dyadic Adjustment " prepared by the researcher on dyadic adjustment, family values and the impact of social support on the dyadic adjustment "Pretest-posttest control group mixed pattern" was used. In order to determine the couples to take place in the experimental and control groups of the research, VS, DAS and HDRS were implemented to the employed and married couples living in Çanakkale by the researcher. As a result of the applications, it is seen that nobody has marking which does not comply with the directives or was seen leaving the items blank, and the couples to form the experimental and control groups were chosen according to the data obtained from 85 women, 85 men, making a total of 170 people, that is 85 couples.

After the pre- procedure measurement was done to the couples, it was tested whether there is a significant difference between groups and implementation phase was put into effect. During the implementation phase, the experimental group was implemented dyadic adjustment psychoeducational program consisting of 10 sessions throughout the 10 weeks. Couples in the control group did not receive any treatment. Applications to the experimental group were completed within 10 weeks and a week after the completion of the last session, VS, DAS and HDRS were implemented as the final test to both groups (experimental and control). In order to test whether "the effect of the Systemic Family Oriented Psycho-Education Program on Values, Perceived Social Support and Dyadic Harmony" is independent of time, ie long-term (permanent) or not, 2 months after the posttest application, again all VS, DAS and HDRS were implemented and monitoring measurements were performed.

\subsection{Data Analysis}

The differences between the experimental and control groups were analyzed by Mann-Whitney U independently. Pretest-posttest and post-monitoring results of the Dyadic Adjustment PsychoEducational Program (DAPEP henceforth) experimental group couples were analyzed with the Wilcoxon signed rank test. By subtracting pretest scores from posttest scores, difference scores were found, and then relating to the points difference between the experimental and control groups, the difference between the average scores, Wilcoxon for unrelated groups and in order to demonstrate the significant difference between what measurements, the Friedman test, and whether there is harmony among the three applications or not are tested with Kendall's coefficient of concordance.

\section{Results}

\subsection{Testing the Hypotheses Regarding the Values}

When Table 1. is analyzed, the scores given by couples in experimental group participated in DAPEP to values, dyadic adjustment scale and multidimensional scale of perceived social support are compared with the Friedman $(\mathrm{X} 2(47 . \mathrm{N}=10)=451,775, \mathrm{p}<.01)$ test, it is seen that there is a statistically significant difference, and as a result of evaluations made by Kendall coefficient of concordance, there is statistically significant compliance $(\mathrm{W}=.961, \mathrm{p}<.01)$. 
Table 1: Friedman and Kendall Test Results of DAPEP Experimental Group Couples' Test Retest - Monitoring Points on Values, Dyadic Cohesion and Multidimensional Scale of Perceived Social Support

\begin{tabular}{lr}
\hline N & 10 \\
Kendall's Wa $^{\text {a }}$ & 0,961 \\
Chi-Square & 451,775 \\
df & 47 \\
Asymp. Sig. & 0 \\
a. Friedman Test & \\
b. Kendall's Coefficient of Concordance & \\
\hline
\end{tabular}

When the differences in the values of the groups are analyzed according to the pre-test and post-test data (Table 2$)$, in the sub-dimensions of social values $(\mathrm{U}=4.000, \mathrm{P}<.05)$, , career values $(\mathrm{U}=3.000, \mathrm{P}<.05)$, intellectual values $(\mathrm{U}=18.500 ; \mathrm{P}<.05)$, spiritual values $(\mathrm{U}=$ $7.500, \mathrm{P}<.05)$, materialistic values $(\mathrm{U}=9.500, \mathrm{P}<.05)$, values of human dignity $(\mathrm{U}=21.000$; $\mathrm{P}<.05)$, romantic values $(\mathrm{U}=17.000 ; \mathrm{P}>.05)$, freedom values $(\mathrm{U}=22.000 ; \mathrm{P}>.05)$ and conquering values $(\mathrm{a}=.000 ; \mathrm{P}>.05)$, between the control and experimental groups, there seems to be significant difference between pretest and posttest scores.

Table 2: Regarding the Values of Experimental and Control Group, Mann-Whitney U Test Data

\begin{tabular}{|c|c|c|c|c|c|c|c|}
\hline Treatment & Sub dimension & Groups & $\mathrm{N}$ & $\begin{array}{c}\text { Rank } \\
\text { Average }\end{array}$ & $\begin{array}{l}\text { Rank } \\
\text { Total }\end{array}$ & $\mathrm{U}$ & $p$ \\
\hline \multirow{18}{*}{$\begin{array}{l}\text { Pretest } \\
\text { Posttest } \\
\text { Difference } \\
\text { Results }\end{array}$} & \multirow{2}{*}{ Social } & Experimental & 10 & 15,1 & 151 & \multirow{2}{*}{4,000} & \multirow{2}{*}{0,000} \\
\hline & & Control & 10 & 5,9 & 59 & & \\
\hline & \multirow{2}{*}{ Career } & Experimental & 10 & 15,2 & 152 & \multirow{2}{*}{3,000} & \multirow{2}{*}{0,000} \\
\hline & & Control & 10 & 5,8 & 58 & & \\
\hline & \multirow{2}{*}{ Intellectual } & Experimental & 10 & 13,65 & 136,5 & \multirow{2}{*}{18,500} & \multirow{2}{*}{0,016} \\
\hline & & Control & 10 & 7,35 & 73,5 & & \\
\hline & \multirow{2}{*}{ Spiritual } & Experimental & 10 & 14,75 & 147,5 & \multirow{2}{*}{7,500} & \multirow{2}{*}{0,001} \\
\hline & & Control & 10 & 6,25 & 62,5 & & \\
\hline & \multirow{2}{*}{ Materialistic } & Experimental & 10 & 14,55 & 145,5 & \multirow{2}{*}{9,500} & \multirow{2}{*}{0,002} \\
\hline & & Control & 10 & 6,45 & 64,5 & & \\
\hline & \multirow{2}{*}{ Human Dignity } & Experimental & 10 & 13,4 & 134 & \multirow{2}{*}{21,000} & \multirow{2}{*}{0,027} \\
\hline & & Control & 10 & 7,6 & 76 & & \\
\hline & \multirow{2}{*}{ Romantic } & Experimental & 10 & 13,8 & 138 & \multirow{2}{*}{17,000} & \multirow{2}{*}{0,012} \\
\hline & & Control & 10 & 7,2 & 72 & & \\
\hline & \multirow{2}{*}{ Freedom } & Experimental & 10 & 13,3 & 133 & \multirow{2}{*}{22,000} & \multirow{2}{*}{0,032} \\
\hline & & Control & 10 & 7,7 & 77 & & \\
\hline & \multirow{2}{*}{ Conquest } & Experimental & 10 & 15,5 & 155 & \multirow{2}{*}{0,000} & \multirow{2}{*}{0,000} \\
\hline & & Control & 10 & 5,5 & 55 & & \\
\hline
\end{tabular}

\subsection{Testing the Hypotheses regarding the Dyadic Adjustment}

Considering the differences between pretest and posttest results of the dyadic adjustment scale of the couples in experimental group participated in DAPEP (Table 3), it is observed that the pre-test and post scores they receive from the sub-dimensions, such as peer reconciliation of couples in the experimental group $(\mathrm{z}=-2809, \mathrm{P}<.05)$, co satisfaction $(\mathrm{z}=-2043, \mathrm{P}<.05)$, peer integration $(\mathrm{z}=-2536, \mathrm{P}<.05)$, and emotional expressions $(\mathrm{z}=-2536, \mathrm{P}<.05)$ were significantly different. 
Table 3: The Couples Participating in the Experimental Group DAPEP Dyadic Adjustment Scale, Pretest and posttest scores, Wilcoxon Signed Ranks Test Results

\begin{tabular}{|c|c|c|c|c|c|c|}
\hline \multicolumn{2}{|c|}{ Pretest - Posttest } & $\mathrm{N}$ & Rank Average & $\begin{array}{l}\text { Rank } \\
\text { Total }\end{array}$ & $\mathrm{z}$ & $p$ \\
\hline \multirow{3}{*}{ Peer Reconciliation } & Negative Rank & $10^{\mathrm{ab}}$ & 5,5 & 55 & \multirow{3}{*}{$-2.809^{b}$} & \multirow{3}{*}{0,005} \\
\hline & Pozitive Rank & $0^{\mathrm{ac}}$ & 0 & 0 & & \\
\hline & Equal & $0^{\mathrm{ad}}$ & & & & \\
\hline \multirow{3}{*}{ Co Satisfaction } & Negative Rank & $8^{\mathrm{ae}}$ & 5,94 & 47,5 & \multirow{3}{*}{$-2.043^{b}$} & \multirow{3}{*}{0,041} \\
\hline & Pozitive Rank & $2^{\mathrm{af}}$ & 3,75 & 7,5 & & \\
\hline & Equal & $0^{\mathrm{ag}}$ & & & & \\
\hline \multirow{3}{*}{ Peer Integration } & Negative Rank & $8^{\mathrm{ah}}$ & 4,5 & 36 & \multirow{3}{*}{$-2.536^{\mathrm{b}}$} & \multirow{3}{*}{0,011} \\
\hline & Pozitive Rank & $0^{\mathrm{ai}}$ & 0 & 0 & & \\
\hline & Equal & $2^{\text {aj }}$ & & & & \\
\hline \multirow{3}{*}{ Emotional Expressions } & Negative Rank & $8^{\mathrm{ak}}$ & 4,5 & 36 & \multirow{3}{*}{$-2.536^{b}$} & \multirow{3}{*}{0,011} \\
\hline & Pozitive Rank & $0^{\mathrm{al}}$ & 0 & 0 & & \\
\hline & Equal & $2^{\mathrm{am}}$ & & & & \\
\hline
\end{tabular}

When Table 4. is examined, in the sub dimensions of the experimental and control groups, such as peer consensus $(\mathrm{U}=0.000, \mathrm{P}<.05)$, co satisfaction $(\mathrm{U}=18.000 ; \mathrm{P}<.05)$, peer integration ( $\mathrm{U}$ $=13.500 ; \mathrm{P}<.05)$ and emotional expression $(\mathrm{a}=10.000 ; \mathrm{P}<.05)$, the difference between pretest and post test scores between the experimental and control groups appears to be significant in favor of the experimental group.

Table 4: Mann-Whitney U Test Results regarding the Couple Harmonization of Individuals in the Control Group and Experiment Group

\begin{tabular}{|c|c|c|c|c|c|c|c|}
\hline Treatment & Sub dimension & Groups & $\mathrm{N}$ & $\begin{array}{c}\text { Rank } \\
\text { Average }\end{array}$ & $\begin{array}{l}\text { Rank } \\
\text { Total }\end{array}$ & $\mathrm{U}$ & $\mathrm{p}$ \\
\hline \multirow{8}{*}{$\begin{array}{l}\text { Pretest } \\
\text { Posttest } \\
\text { Difference } \\
\text { Results }\end{array}$} & \multirow{2}{*}{ Peer Reconciliation } & Experimental & 10 & 15.50 & 155 & \multirow{2}{*}{0,000} & \multirow{2}{*}{0,000} \\
\hline & & Control & 10 & 5.50 & 55 & & \\
\hline & \multirow{2}{*}{ Co Satisfaction } & Experimental & 10 & 13.70 & 137 & \multirow{2}{*}{18,000} & \multirow{2}{*}{0,014} \\
\hline & & Control & 10 & 7.30 & 73.00 & & \\
\hline & \multirow{2}{*}{ Peer Integration } & Experimental & 10 & 14.15 & 141.50 & \multirow{2}{*}{13,500} & \multirow{2}{*}{0,001} \\
\hline & & Control & 10 & 6.85 & 68.50 & & \\
\hline & Emotional & Experimental & 10 & 14.50 & 145.00 & \multirow[t]{2}{*}{10,000} & \multirow{2}{*}{0,001} \\
\hline & Expressions & Control & 10 & 6.50 & 65.00 & & \\
\hline
\end{tabular}

\subsection{Testing the Hypotheses regarding the Perceived Social Support}

When Table 5. İs examined, it is seen that there are significant differences between the pretest and posttest results obtained by the couples surveyed in the experimental group in the following sub dimensions, such as family $(\mathrm{z}=-2,670, \mathrm{p}<.05)$, friend $(\mathrm{z}=-1889, \mathrm{P}<.05)$, and private one $(\mathrm{z}=-2810, \mathrm{P}<.05)$. 
Table 5: Wilcoxon Signed Ranks Test Results of the Pretest and Psttest Scores of the Couples Participating in the Experimental Group of DAPEP on Multidimensional Scale of Perceived Social Support

\begin{tabular}{|c|c|c|c|c|c|c|}
\hline Pretes & sttest & $\mathrm{N}$ & Rank Average & $\begin{array}{l}\text { Rank } \\
\text { Total }\end{array}$ & $\mathrm{Z}$ & $p$ \\
\hline & $\begin{array}{l}\text { Negative } \\
\text { Rank }\end{array}$ & $9^{\text {an }}$ & 5 & 45 & & \\
\hline Family & $\begin{array}{l}\text { Pozitive } \\
\text { Rank }\end{array}$ & $0^{\text {ao }}$ & 0 & 0 & $-2.670^{\mathrm{b}}$ & 0,008 \\
\hline & Equal & $1^{\mathrm{ap}}$ & & & & \\
\hline & $\begin{array}{l}\text { Negative } \\
\text { Rank }\end{array}$ & $2^{\mathrm{aq}}$ & 4,5 & 9 & & \\
\hline Friend & $\begin{array}{l}\text { Pozitive } \\
\text { Rank }\end{array}$ & $8^{\mathrm{ar}}$ & 5,75 & 46 & $-1.889 c$ & 0,059 \\
\hline & Equal & $0^{\text {as }}$ & & & & \\
\hline & $\begin{array}{l}\text { Negative } \\
\text { Rank }\end{array}$ & $10^{\text {at }}$ & 5,5 & 55 & & \\
\hline Private One & $\begin{array}{l}\text { Pozitive } \\
\text { Rank }\end{array}$ & $0^{\mathrm{au}}$ & 0 & 0 & $-2.810 b$ & 0,005 \\
\hline & Equal & $0^{\mathrm{av}}$ & & & & \\
\hline
\end{tabular}

When Table 6. is analyzed, it is seen that there are significant differences in favor of the experimental group between the pretest and posttest results obtained by the couples surveyed in the experimental group and control group in the following sub dimensions, such as family $(\mathrm{a}=$ $8.500 ; \mathrm{P}>.05)$, friends $(\mathrm{U}=22.500 ; \mathrm{P}>.05)$, and a private one $(\mathrm{a}=6.000 ; \mathrm{P}>.05)$.

Table 6: Experimental and Control Group Couples Family, Friends and Private one Values PreTest - Posttest Mann-Whitney U Results

\begin{tabular}{|c|c|c|c|c|c|c|c|}
\hline Treatment & $\begin{array}{l}\text { Sub } \\
\text { dimension }\end{array}$ & Groups & $\mathrm{N}$ & $\begin{array}{c}\text { Rank } \\
\text { Average }\end{array}$ & $\begin{array}{l}\text { Rank } \\
\text { Total }\end{array}$ & $\mathrm{U}$ & $p$ \\
\hline \multirow{6}{*}{$\begin{array}{l}\text { Pretest Posttest } \\
\text { Difference } \\
\text { Results }\end{array}$} & \multirow{2}{*}{ Family } & Experimental & 10 & 14.65 & 146,5 & \multirow{2}{*}{8,500} & \multirow{2}{*}{0,002} \\
\hline & & Control & 10 & 6.35 & 63,5 & & \\
\hline & \multirow{2}{*}{ Friend } & Experimental & 10 & 7.75 & 77,5 & \multirow{2}{*}{22,500} & \multirow{2}{*}{0,036} \\
\hline & & Control & 10 & 13.25 & 132,5 & & \\
\hline & \multirow{2}{*}{ Private One } & Experimental & 10 & 14.90 & 149 & \multirow{2}{*}{6,000} & \multirow{2}{*}{0,001} \\
\hline & & Control & 10 & 6.10 & 61 & & \\
\hline
\end{tabular}

\section{Discussion and Conclusion}

The findings derived from statistical analysis applied to the pretest, posttest and monitoring test scores of the values of the couples contained in the experimental and control groups were discussed in accordance with the basic and sub-hypotheses of the study. As a result of the study, in the values, dyadic adjustment and social support scores of the couples in the experimental group, it was found that there was an increase in favor of the post test and it showed differences from pre-test and control groups.

In the psycho - educational program prepared to test the effect of dyadic adjustment and in which values are taught, the results obtained from the experimental group are seen to have significant differences. This result is supported by various studies. Smith, and Wozniak (2010) state the solidarity of family members and that they share common family values reflecting the importance of individual equality under parental guidance, and Samur (2011) says that values education program can support social and emotional development of children in a positive way.In psycho-education, it can be interpreted as that couples involved the experimental group developed value orientations positively compared to couples in the control group. Considering 
the structural research on family, it is understood that the focus points are on the durability of the institution of marriage, as it serves the approval of couples by the society and their institutionalization (Rossi, 2014). Values on the one hand affect cognitive processes, attitudes and behaviors, on the other hand interact with the cultural patterns of the community. Values which are long-term as they are the principles and criteria shared by society and culture, and also because of their dynamic structures, may slowly vary from society to society and according to the spirit of the time (Arends-Toth \& van der Vijver, 2009). It can be said that values the family members have may have a positive effect on marriage compliance. Together with modernization, as can be seen from the decrease in the rate of marriages and child- bearing and the increase in divorces, the continuity of the family institution is at serious risk, and it is observed that many family values, such as the importance of marriage and family, the appraised value of the child and so on lose their functioning. As a result of functional changes experienced not only in psycho-physiological dimension but in socio-economic dimension as well, family values are differentiated substantially; for example, women's taking a place in work life, providing economic contributions to family duties and taking responsibility, and with the expansion of the nuclear family, the roles in family, decision-making and sharing of authority, parent-child attachment level, the kinship relations, and social assistance levels (Chang, \& Perl, 1999; Sotomayor-Peterson et al., 2012; Albert, Ferring \& Michels, 2013; Iruonagbe, Chiazor \& Foluke, 2013; Abay \& Atila Demir, 2014).

The research results revealed that peer consensus, co satisfaction, peer integration and and emotional expression are in an increased level and persistent affecting the marital adjustment of the couples who participated in the application in the experimental group. This result is supported by various research studies. Gürsoy (2004) states that the variables that affect marital adjustment are care, education and the work status; Tezer et al. (2005) state that marital harmony does not vary according to the size of perfectionism; Sardoğan and Karahan (2005) state that "Human Relations Skill Training Program" affects the marital harmony positively, and Erberk et al (2005) say that sexuality and marital adjustment are found to be at high level. Cultural and religious changes in the social structure entered the lives of individuals and families and revealed obvious changes in issues from couples' marriage style to forming the descendants, and from seats to the number of children (Arends-Toth \& van der Vijver, 2009; Iruonagbe, Chiazor \& Foluke, 2013). Naturally, if a fault occurs in the family institution, this will reveal negative consequences both with the individual and in a broader sense with the society, and it will also constitute a major problem for the future in terms of values (SotomayorPeterson ve ark., 2012; Iruonagbe, Chiazor \& Foluke, 2013).

With the systemic family approach, it is understood that there are differences between the pretest - posttest - and monitoring results of the multidimensionally detected social support scale of the couples receiving psycho-educational practice field, and with the results of the evaluation with Kendall's coefficient of concordance, there is a statistically significant adaptation. This result is supported by various research studies. Jackson, Tucker and Herman (2007) stated that the value of health and health-related self-efficacy force a healthy lifestyle; Friedlander, Reid, Shupak and Gribbie (2007) revealed that when perceived social support from friends increases, it affects the harmony of couples to school positively. Many of the social support activities see social support as a coping strategy when individuals usually use in a difficult situation. Seeing social support as a source of coping and basing the theoretical infrastructure on buffer effect models, these activities argue that social support is a powerful resource that can be used in solution, treatment and prevention of the sociological, psychological and even biological problems of the individuals (Melrose, Brown \& Wood, 2015; De La Iglesia, Stover, Fernandez Liporace M., 2014; Chung, Moser, Lennie \& Frazier, 2013). For this reason, perceived social support activities are still being studied in more depth as a concept in almost every area in which human beings take place (eg. education, health services, business, etc.) (De La Iglesia, Stover, Fernandez Liporace M., 2014; Song ve ark., 2014; De La Iglesia, Hoffman \& Liporace, 
2014). Perceived social support is simply defined as the belief of the individual to get help when needed (Zhou et al., 2013; Melrose, Brown \& Wood, 2015). Perceived support consists of both that support can be gained and the satisfaction to be gained by support (Melrose, Brown \& Wood, 2015). Origin-family support perceptions of the couples will make their marriage lives quality.

The results obtained in this study showed that values and perceived social support are influential on the dyadic adjustment. Therefore, values can be used in the planning and implementation of activities concerning couples whose dyadic adjustment and perceived social support are low. The psycho-educational program applied with systemic family counseling approach both improves the dyadic adjustment and contributes to marriage as well. By increasing the value orientation of the couples, it can be contributed to their adjustment. It can be said that the couples improved their social support perceptions. Other variables can also be regarded in the research which are thought to affect marital adjustment. In this study, the main purpose of the psycho-educational programs whose effectiveness is tested is to help to improve the compatibility of couples. As a result of the research, it was found that the psycho-educational program was effective on concepts, such as values, dual compliance and multi-dimensionally perceived social support. It can be concluded that the couples who participated in the study in the experimental group affected and improved the values, marital adjustment, and perceptions of social support.

\section{References}

Abay, A. R. \& Atila Demir, S. (2014). Belli Parametrelere Göre Kuşaklararası Sosyal Değişme (Aile Değerleri Üzerine Bir Karşılaştırma). Akademik Incelemeler Dergisi, (Intergenerational Social Change by certain parameters (A Comparison on Family Values). Academic Research Journal), 9 (1),125-151.

Albert, I., Ferring, D. \& Michels, T. (2013). Intergenerational Family Relations in Luxembourg: Family Values and Intergenerational Solidarity in Portuguese Immigrant and Luxembourgish Families. European Psychologist, 18 (1), 59-69.

Arends-Toth, J. \& van der Vijver, F. J. R. (2009). Cultural differences in family, marital, and gender-role values among immigrants and majority members in the Netherlands. International Journal of Psychology, 44 (3), 161-169.

Aydın, M. (2003). Gençliği Değer Algısı: Konya Örneği. Değerler Eğitimi Dergisi (Youth's Value Perception: The Case of Konya. Values Education Journal), 1, 121-144.

Ayral, A. E. (1992). Akademisyenlerin Çalışmayla İlgili Değerleri.Yayınlanmamış yüksek lisans tezi. Marmara Üniversitesi, Sosyal Bilimleri Enstitüsü, İngilizce İşletme Bölümü Organize Davranışlar Ana Bilim Dalı, (Values of Academics Related to Working. Unpublished master's thesis. Marmara University, Institute of Social Sciences, Department of Business Administration, Department of Organized Behaviour)

Batool, N. (2014). Work-Life Balance and Perceived Social Support among College Lecturers. Pakistan Business Review, 123-142.

Bauman, S.S.M., Wang, N., Deleon, C.W., Kafentzis, J., Zavala-Lopez, M., \& Lindsey, M.S. (2004). Nontraditional Students' Service Needs And Social Support Resources: A Pilot Study. Journal Of College Counseling, 7(1), 13-17.

Branje, S. J. T., van Aken, M.A. G. ve van Liesh, C. F. M. (2002). Relational Support in Families With Adolescents. Journal of Family Psychology, 16(3), 351-362

Caplan, G. (1974). Support Systems and Community Mental Health: Lectures on Conceptual Development. New York: Behavioral Publications. 
Chang, P.M.Y. \& Perl, P. (1999). Enforcing Family Values? The Effects of Marital Status on Clergy Earnings. Sociology of Religion, 60 (4), 403-417.

Chung, M.L., Moser, D.K., Lennie, T.A. \& Frazier, S.K. (2013). Perceived social support predicted quality of life in patients with heart failure, but the effect is mediated by depressive symptoms. Quality of Life Research Journal, 22 (7), 1555-63.

Deaton, A. V. (1998). Treating Conversion Disorders: Is A Pediatric Rehabilitation Hospital The Place? Rehabilitation Psychology, 43(1), 56-62.

De La Iglesia, G., Hoffmann, A.F. \& Fernandez Liporace, M. (2014). Perceived parenting and social support: can they predict academic achievement in Argentinean college students? Psychology Research and Behavior Management, 7, 251-259.

De La Iglesia G, Stover JB, Fernandez Liporace M. (2014). Perceived Social Support and Academic Achievement in Argentinean College Students. Europe's Journal of Psychology, 10 (4), 637-649.

Dilmaç, B. and Arıcak, O.T. (16-18 November 2012). Değerler Ölçeği Geçerlilik ve Güvenirlik Çalışması.2. Uluslararası Değerler Eğitimi Sempozyumu (Value Scale Validity and Reliability Study. 2nd International Symposium on Values Education), İstanbul.

Eker, D., Arkar, H. and H. Yalzdı (2001). Çok Boyutlu Algılanan Sosyal Destek Ölçeği'nin Gözden Geçirilmiş Formu Faktör Yapısı, Geçerlik Ve Güvenirliği. Türk Psikiyatri Dergisi (Multidimensional Scale of Perceived Social Support Revised Form Factor Structure, Validity and reliability. Turkish Journal of Psychiatry), 12(1),17-25

Ersanlı, K. and Kalkan M. (2008). Evlilik İlişkilerini Geliştirme Kuram Ve Uygulama. Ankara: Nobel Yayınları. (Development of Marriage Relationship, the Theory and Practice. Ankara: Nobel Publishing.)

Glading, S., T. (1998). Family Therapy: History Theory And Practice. Seconded. New Jersey: Merrill, Prentice - Hall,

Güngör, E. (1993). Değerler Psikolojisi. Amsterdam:Hollanda Türk Akademisyenler Birliği Vakfi Yayınları, (Values Psychology. Amsterdam: Dutch Turkish Academics Union Foundation Publications),

Güngör, A. (1996) Üniversite Çiftlerinde Sosyal Destek, Negatif Yaşam Olayları, Öfkenin İfade Ediliş Biçimi İle Kendini Suçlamanın Fiziksel Sağlık Ve Sosyal Uyumla Olan İlişkilerinin İncelenmesi. Yayımlanmamış Yüksek Lisans Tezi. Hacettepe Üniversitesi. ( With University Couples Social Support, Negative Life Events, Way of Expressing Anger, and Investigation of the Physical and Health and Social Relations Compliance. Unpublished Master's Thesis. Hacettepe University.)

Hupcey, J.E. (1998). Clarifying The Social Support Theory-Research Linkage. Journal of Advanced Nursing, 27, 1231-1241.

Iruonagbe, T. C., Chiazor, I. A. \& Foluke, A. (2013). Revisiting Family Values: A Pathway towards Societal Stability. Gender \& Behaviour, 11(2), 5635-5642.

Janicki, D.L., Kamarck, T.W., Gwaltney, C.J., Shiffman, S. (2006). Application Of Ecologial Momentary Assessment To The Study Of Marital Adjustment And Social İnteractions During Daily Life. Journal Of Family Psychology, 20(1), 168-172.

Jagger, G., \& Wright, C.(1999). Changing Family Values: Feminist Perspectives. USA:Routledge.

Jung, J. (1987). Toward a Social Psychology of Social Support. Basic and Applied Social Psychology, 8( 1-2), 57-83.

Koerner, A.and Fitzpatrick, M. (2006). Family Conflict Communication. In J. Oetzel \& S.S Ting-Toomey (Eds.), The Sage Hand Book Of Conflict Communication: Integrating Theory, Research and Practice. (159-183). Thousandoaks, Ca Sage.

Kulaksızoğlu, A. and Dilmaç, B. (2000). İnsani Değerler Eğitimi Programı. Marmara Üniversitesi, Atatürk Eğitim Fakültesi, Eğitim Bilimleri Dergisi, Sayı:12. (Humane Values Education Program. Marmara University, Faculty of Education, Journal of Educational Studies, Issue 12). 
Kuşdil, M.E., \& Kağıtçıbaşı, Ç. (2000). Türk Öğretmenlerin Değerler Yönelimi Ve Schwartz Değer Kuram1, Türk Psikoloji Dergisi (Values Orientation and the Schwartz Value Theory of Turkish Teachers, Turkish Journal of Psychology), 15 (45), 59-76.

Lee, C.M. (2010). Families Matter: Psychology Of The Family and The Family Of Psychology. Canadian Psychology, 51(1), 1-8.

Lepora, S. J. Evans, G.W. Schneider, M. L. (1999). Dynamic Role Of Social Support İn The Link Between Chronic Stress And Psychological Distress. Journal Of Personality And Social Psychohgy, 899-909.

Marvin, R. S. (1992). Attachment And Family Systems-Based İntervention İn Developmental Psychology. Development And Psychopathology, 4, 697-711.

Melrose, K.L., Brown, G.D.A. \& Wood, A. M. (2015). When is received social support related to perceived support and well-being? When it is needed. Personality and Individual Differences, 77, 97-105

Mert, A. (2014) Sistemik Aile Yönelimli Psiko-Eğitim Programının Değerler, Algılanan Sosyal Destek Ve Çift Uyumuna Etkisi. Yayımlanmamış Doktora Tezi. (Value of Systemic Family Oriented Psycho-Education Program, The Effect of Perceived Social Support and Dyadic Adjustment. Unpublished PhD Thesis). Sakarya

Mischel, W. (1990). Personality Dispositions Revisited And Revised: A View After

Özgüven, İ.E., (2000). Evlilik ve Aile Terapisi (Marriage and Family Therapy). Ankara: Pdrem Yayınları (Publishing).

Pearlin, L.I., Harrington, C., Powell-Lawton,M.,Montgomery,R.J.V. and Zarit, S.H. (2001). An Overview Of Social And Behavioural Consequences Of Alzheimer's Disease. Aging And Mental Health, 5, 1, 3-6.

Pearson, R. E. (1990). Other And Context Based Barriers. In R.E. Pearson (Ed.) Counseling And Social Support: Perspectives And Practice (pp. 122-142), Newbury Park: CA: Sage Publishing.

Peter, P. J. \& Olson, J. C. (2005). Consumer Behavior And Marketing Strategy, Seventh Edition, Mcgraw-Hill Higher Education.

Procidano, M, Heler, K.( 1983) Measures Of Perceived Social Support From Friends And From Family: Tree Validation Studies. American Journal Of Commumty Psychology, $N(L) ; \backslash-24$,

Ritvo, E. C., Glick, I. D. (2002). Concise Guide To Marriage And Family Therapy. Washington, D. C: American Psychiatric Publishing, Inc.

Rokeach, M. (1973). The Nature Of Human Values. New York: Free Pres.

Rokeach, M. (1968). Beliefs, Attitudes and Values. SanFrancisco: Jossey-Bass.

Rossi, G. (2014). The Complex Relationship Between Values and Couple Patterns. Journal of Comparative Family Studies, 45 (1), 173-199.

Rueter, M. A., \& Koerner, A. F. (2008). The Effect of Family Communication Pattern On Adopted Adolescent Adjustment. Journal Of Marriage And Family, 70, 715-727.

Sabatelli, R.M. (1988). Measurement Issues in Marital Research: Areview And Critique Of Contemporary Survey Instruments. Journal Of Marriage And The Family, 50, 891915.

Sarason, I. G., Pierce, G. R., \& Sarason, B. R. (1990). Social Support And İnteractional Processes: A Triadic Hypothesis. Journal of Social and Personal Relationships, 7, 495-506.

Sarason, I. G., Levine, H. M., Basham, R. B.,Sarason, B. R., (1983). Assesing Social Support: The Social Support Questionnaire. Journal Of Personality And Social Psychology, 44 (1), 127-139

Schiffman, L.G. \& Kanuk, L.L.(2004). Consumer Behavior. Eight Edition, India: Prentice Hall

Schwartz, S. (1992). Universals In The Content And Structure Of Values: Theoretical Advances And Empirical Tests In 20 Countries. In M. P. Zanna, (Ed.), Advances In Experimental Social Psychology (Pp.1-65). San Diego: Academic Press, 
Schwartz, S. H., \& Bilsky, W. (1987). Toward A Universal Psychological Structure Of Human Values. Journal of Personality and Social Psychology, 53, 550-562.

Schwartz, S. H., \& Boehnke, K. (2004). Evaluating The Structure Of Human Values With Confirmatory Factor Analysis. Journal of Research in Personality, 38, 230-255.

Shumaker, S.A., \& Brownell, A. (1984). Toward A Theory Of Social Support: Closing Conceptual Gaps. Journal of Social Issues, 40(4), 11-36.

Spanier, G.B. (1976). Measuring Dyadic Adjustment: New Scales For Assessing The Quality Of Marriage And Similar Dyads. Journal Of Marriage And The Family, 1528.

Seltzer, W. J. (1985). Conversion Disorder İn Childhood And Adolescence: A Familial/Cultural Approach. Family Systems Medicine, Part I. 3, 261-280.

Song, J., Bong, M., Lee, K. \& Kim, S. (2014). Longitudinal Investigation into the Role of Perceived Social Support in Adolescents' Academic Motivation and Achievement. Journal of Educational Psychology, 1-21.

Sorias, O. (1998) Sosyal Destekler Ve Ruh Sağlığı. Ege Üniversitesi Tip Fakültesi Dergisi (Social Support and Mental Health. Ege University Faculty of Medicine Journal), 27(1): 359-362.

Sotomayor-Peterson, M., Figueredo, A.J., Christensen, D.H. \& Taylor, A.R. (2012). Couples' Cultural Values, Shared Parenting, and Family Emotional Climate Within Mexican American Families. Family Process, 51 (2), 218-233.

Tutarel-Kışlak, Ş. (1997). Evlilik Uyumu İle Nedensellik Ve Sorumluluk Yüklemeleri Arasındaki İlişkiler. Türk Psikoloji Dergisi (Relations Between the Marital Adjustment and Causality and Responsibility. Turkish Journal of Psychology), 12(40), 55-64.

Wells, W.D. \& Prensky, D.(1996). Consumer Behavior, John Wiley \& Sons, Inc.

Wilson, A.(1985). Family Therapy. Routledge, USA.

Sabatelli, R.M. (1988). Measurement Issues in Marital Research: Areview And Critique Of Contemporary Survey Instruments. Journal Of Marriage And The Family, 50, 891915.

Wilkinson, L.(1998). Child And Family Assessment Clinical Guidelines For Practitioners (2nd Edition). Brunner-Routledge, USA.

Veiel, H. O. \& Bauman, U. (1992). The Many Meanings of Social Support. In H.O. Veiel \& U. Bauman (Eds.), The Meaning and Measurement of Social (pp. 1-9). New York: Hemisphere.

Yapıc1, A. (2004). Din, Kimlik Ve Ön Yarg1: Biz Ve Onlar (Religion, Identity and Prejudice: Us and Them). Karahan Kitabevi (Bookstore), Adana.

Yıldırım, İ. (1997). Algılanan Sosyal Destek Ölçeğinin Geliştirilmesi, Güvenirliği ve Geçerliği. Hacettepe Üniversitesi Ĕgitim Fakültesi Dergisi (Development, Reliability and Validity of Perceived Social Support Scale. Hacettepe University Faculty of Education Journal), (13), 81-87.

Young, J.F., Berenson, K., Cohen, P., \& Garcia, J. (2005). The Role Of Parent And Peer Support İn Predicting Adolescent Depression: A Longitudinal Community Study. Journal Of Research On Adolescence, 15(4), 407-423.

Zhou, X., Zhu, H., Zhang, B. \& Cai, T. (2013). Perceived social support as moderator of perfectionism, depression, and anxiety in college students. Social Behavior and Personality: An International Journal, 41 (7), 1141-1152.

Zimet, G. D., Dahlem, N. W., Zimet, S. G., \& Farley, G. K. (1988). The Multidimensional Scale Of Perceived Social Support. Journal of Personality Assessment, 52(1), 30-41. 